\title{
AOR
}

Selected Papers of \#AolR2021:

The 22nd Annual Conference of the Association of Internet Researchers Virtual Event / 13-16 Oct 2021

\section{THE ROLE OF COMMUNICATION AFFORDANCES IN POST-TRAUMATIC STRESS DISORDER SUPPORT GROUPS ON FACEBOOK AND WHATSAPP}

Daphna Yeshua-Katz

Ben-Gurion University of the Negev

\section{Background}

Digital health research has highlighted the fact that people with stigmatized health disorders are drawn to online support group (OSG) because these groups help them to manage their stigmatized health conditions. However, little is known about how media affordances - the outcomes of the relation between the technology and the user (Evans et al., 2017; Gibson, 1977)—reconfigure the ways in which stigmatized individuals use OSG and interact with others like themselves. The current study applied an affordance framework to evaluate how Facebook and WhatsApp support groups can help military veterans and their partners cope with posttraumatic stress disorder (PTSD).

\section{Method}

This paper presents findings from in-depth interviews with 34 members of PTSD-OSGs. These interviews captured participants' voices as they told their stories, creating detailed representations of their experiences in PTSD-OSGs. To identify the themes emerging from the interviews, we conducted an inductive thematic analysis (Braun \& Clarke, 2006). This process resulted in13 thematic categories were further reduced to five underlying concepts-visibility, availability, multimediality, surveillance, and synchronicity - all central to the communication affordances framework (Boyd, 2010; Coulson, 2017; Ellison et al., 2016; Evans et al., 2017; Treem \& Leonardi, 2013) (see Table 2 for thematic categories).

Table 2: Thematic categories

\begin{tabular}{|l|l|l|}
\hline Affordances & Themes & Participants' quotes \\
\hline Visibility & $\begin{array}{l}\text { Public nature } \\
\text { of posts }\end{array}$ & $\begin{array}{l}\text { I know some say WhatsApp is } \\
\text { private. That's bullshit. You have to } \\
\text { be very careful and even more } \\
\text { careful what you write on Facebook. }\end{array}$ \\
\hline
\end{tabular}

Suggested Citation (APA): Yeshua-Katz, D. The Role of Communication Affordances in Post-traumatic Stress Disorder Support Groups on Facebook and WhatsApp. Paper presented at AolR 2021: The 22nd Annual Conference of the Association of Internet Researchers. Virtual Event: AolR. Retrieved from http://spir.aoir.org. 


\begin{tabular}{|l|l|l|}
\hline & & $\begin{array}{l}\text { I am very careful not to write } \\
\text { anything suicidal. }\end{array}$ \\
\hline & $\begin{array}{l}\text { Disclosing } \\
\text { PTSD } \\
\text { condition }\end{array}$ & $\begin{array}{l}\text { Lots of people commented on my } \\
\text { first post. It filled me with lots of } \\
\text { energy. On the other hand, it } \\
\text { stressed me terribly because I'm not } \\
\text { used to this level of exposure. }\end{array}$ \\
\hline Anonymity & $\begin{array}{l}\text { There is no anonymity. Not in the } \\
\text { WhatsApp group and not on } \\
\text { Facebook. I tried to make our } \\
\text { Facebook group as anonymous as } \\
\text { possible. If you're not a member, but } \\
\text { you're looking for the group, you } \\
\text { can't see the posts published, but } \\
\text { you can see who the members are. }\end{array}$ \\
\hline Availability & $\begin{array}{l}\text { I can upload a post at 3 am and } \\
\text { know that there will be immediate } \\
\text { comments. Lots of group members } \\
\text { are awake, and they'll respond } \\
\text { immediately. }\end{array}$ \\
\hline Immediacy
\end{tabular}




\begin{tabular}{|l|l|l|}
\hline & & $\begin{array}{l}\text { someone writes, "Enough is enough" } \\
\text { because he can kill himself within 15 } \\
\text { minutes." }\end{array}$ \\
\hline (A)synchronicity & $\begin{array}{l}\text { Ongoing } \\
\text { communication }\end{array}$ & $\begin{array}{l}\text { Once people felt comfortable in the } \\
\text { offline group, they continued } \\
\text { connecting on the WhatsApp group } \\
\text { and kept talking about the training. }\end{array}$ \\
\hline & $\begin{array}{l}\text { Discontinuous } \\
\text { communication }\end{array}$ & $\begin{array}{l}\text { Communication on Facebook works } \\
\text { like movie cuts. A few days after } \\
\text { writing about my trauma, I can } \\
\text { upload entirely different content, like } \\
\text { a selfie with my nephew, and no one } \\
\text { remembers I wrote something hard } \\
\text { and painful. }\end{array}$ \\
\hline & $\begin{array}{l}\text { On Facebook, we have control. We } \\
\text { controlling look away when we feel like it, } \\
\text { and we do not have to give in to any } \\
\text { communication } \\
\text { intrusive. It's nothing. }\end{array}$ \\
\hline
\end{tabular}

\section{Findings}

This research identified five affordances that members appraised to enhance their coping efforts in the digital world: visibility, availability, multimediality, surveillance, and synchronicity.

Visibility.The potential visibility of online content played a significant role in deciding which digital platform to use. Although most participants already used multiple groups on Facebook and WhatsApp, most found WhatsApp to be a safer space for support. They perceived the WhatsApp group as a closed space that guaranteed a low level of visibility and less risk of online disclosure. Participants felt that this low visibility safeguarded their online content from being posted outside the boundaries of the group.

Availability. Compared to Facebook, most participants preferred to use WhatsApp because its high availability enabled them to reach out to the group in times of need. The ease of entering the group via the app and the group members' immediate responses were significant advantages. Nevertheless, a few participants felt that this high availability was burdensome at times and the group's frequent communications became an additional source of distress.

Multimediality. The group members highlighted the benefits of providing and receiving information in various configurations such as text, image, audio, and video. Group members took advantage of their phones' multimediality and found new and creative ways to cope with their distress. Nevertheless, some participants were unable to use all of the configurations available because their phone capacity did not allow for such large files 
Surveillance. In their search for support, group admins and group members found WhatsApp to be a useful tool because of its surveillance affordance, defined as the ability to monitor group members' behavior. Surveillance was exercised in two ways: through notifications about message status and notifications about members leaving the group.

Synchronicity. When considering the different synchronicity levels afforded by WhatsApp and Facebook, WhatsApp synchronous communication seemed to serve as a hindrance; that is, participants felt that their call for emotional support was left unanswered because of the too-prompt interactions in the group. Participants preferred the asynchronous and turn-taking type of interaction Facebook offered them for more organized forms of communication.

\section{Conclusion}

This study reveals the connection between a specific stigmatizing mental health disorder (i.e., PTSD), perceptions of communication technologies (i.e., affordances), and specifies uses of technologies for coping with this mental health disorder. Moreover, this study may inform digital intervention designers about which communication affordances can potentially lead to better health outcomes.

\section{References}

Boyd, D. (2010). Social network sites as networked publics: Affordances, dynamics, and implications. In A networked self (pp. 47-66). Routledge.

Braun, V., \& Clarke, V. (2006). Using thematic analysis in psychology. Qualitative Research in Psychology. https://doi.org/10.1191/1478088706qp063oa

Coulson, N. S. (2017). Affordance theory can help understanding of individuals' use of online support communities. British Journal of Health Psychology, 22(3), 379382. https://doi.org/10.1111/bjhp.12247

Ellison, N. B., Blackwell, L., Lampe, C., \& Trieu, P. (2016). "The question exists, but you don't exist with it": Strategic anonymity in the social lives of adolescents. Social Media+ Society, 2(4), 2056305116670673.

Evans, S. K., Pearce, K. E., Vitak, J., \& Treem, J. W. (2017). Explicating Affordances: A Conceptual Framework for Understanding Affordances in Communication Research. Journal of Computer-Mediated Communication, 22(1), 35-52. https://doi.org/10.1111/jcc4.12180

Gibson, J. J. (1977). The theory of affordances. In Hilldale, USA (Issue 2).

Treem, J. W., \& Leonardi, P. M. (2013). Social media use in organizations: Exploring the affordances of visibility, editability, persistence, and association. Annals of the 
International Communication Association, 36(1), 143-189.

https://doi.org/10.1080/23808985.2013.11679130 